\title{
OF PROPERTY RULES, COASE, AND INTELLECTUAL PROPERTY
}

\author{
Robert P. Merges*
}

My colleagues in this Symposium have done a fine job of cataloguing the many merits (and occasional lapses) of the paper by Jerry Reichman on which I am asked to comment. ${ }^{1}$ I cannot add much to this theme. I would like instead to take the Reichman paper as an opportunity to comment on certain foundational issues in the law of intellectual property rights (IPRs). Taking my cue from Reichman's characterization of his approach as an "off-the-rack liability rule" regime, ${ }^{2}$ in this Comment I discuss the simple economics of the strong preference for injunctionsthe classic instance of a property rule-in IPR law. I conclude that proponents of IPR liability rules (including, apparently, Reichman) carry a heavy burden.

According to the foundational literature on legal entitlements, ${ }^{3}$ a property rule is a legal entitlement that can only be infringed after bargaining with the entitlement holder. The holder thus sets the price for infringing ex ante. Under a liability rule, by contrast, one may infringe first, and a tribunal will determine the appropriate compensation in an $e x$ post proceeding. Ever since Calabresi and Melamed, transaction costs have dominated the choice of the proper entitlement rule, with a liability rule being the entitlement of choice when transaction costs are high.

Some of this thinking finds its way into Reichman's proposals. ${ }^{4}$ To the extent it does, I take issue. In my view, property rules can and do work effectively in many situations involving IPRs. This is so because, in the presence of high transaction costs, industry participants have an incentive to invest in institutions that lower the costs of IPR exchange. Thus, at least in some cases, the costly bargaining occasioned by a strong property rule leads to an administrative structure that serves much the same function as a statutory liability rule. Consequently, the benefits of lower transaction costs may be achieved without sacrificing the strong property rule built into most IPRs.

* B.S. Carnegie-Mellon; J.D. Yale; Ll.M. Columbia. I would like to thank Paul Goldstein, Wendy Gordon, Steve Marks, Manuel Utset and the participants in this Symposium for helpful comments, and Major League Baseball, whose strike eliminated my best excuse for not working on this piece.

1. See J.H. Reichman, Legal Hybrids Between the Patent and Copyright Paradigm, 94 Colum. L. Rev. 1501 (1994).

2. Id. at 2533. "Off the rack" is a phrase that conjures up the literature on contract default rules. Reichman does not pursue this theme, but it is applied to several related areas in Robert P. Merges, Patent Law and Policy: Cases and Materials 898-900 (1992).

3. See Guido Calabresi \& A. Douglas Melamed, Property Rules, Liability Rules, and Inalienability: One View of the Cathedral, 85 Harv. L. Rev. 1089, 1092 (1972).

4. See Reichman, supra note 2, at 2447. 
As explained in Part II, the pre-infringement bargaining called for by a strong property rule is appropriate for the IPR field, where unique assets are exchanged. Part III briefly describes the exceptions to the strong property rule baseline in the law of IPRs, the compulsory licensing provisions of the various IPR statutes. A general critique of those provisions is also presented. Before jumping into the discussion of property rules and liability rules, however, it is appropriate to consider first whether entitlement rules really matter. This of course is the domain of the Coase Theorem, and of Part I, to which I now turn.

\section{IPRS AND THE COASE TheOREM: OR, WHY THE INDIFFERENCE Thesis FAILS}

A natural starting point when discussing the property/liability rule distinction, or indeed any aspect of entitlements, is the Coase Theorem. ${ }^{5}$ The Theorem says that in a world with zero transaction costs, initial rights allocations are unimportant; they will be transferred to their highestvalue use through private bargains. ${ }^{6}$ But where transaction costs are positive, this result cannot be assumed. Thus, ultimately Coase admonishes us to pay attention to transaction costs in allocating property rights and

5. The theory was first stated, though not under that name, in R.H. Coase, The Problem of Social Cost, 3 J.L. \& Econ. 1 (1960). See generally Robert D. Cooter, Coase Theorem, in 1 The New Palgrave: A Dictionary of Economics 457, 458 (John Eatwell et al. eds., 1987) (presenting overview of Theorem).

6. Coase wrote the article primarily to refute the conventional wisdom associated with A.C. Pigou regarding economic externalities. See Robert D. Cooter, The Coase Theorem, in Allocation, Information and Markets: The New Palgrave 64, 69 (1987) (citing and discussing A.C. Pigou, The Economics of Welfare (4th ed. 1932)). Externalities are effects of one's behavior on others' activities. Pigou stated that externalities could be overcome only through state intervention. For example, he argued that a tax was needed when a business caused smoke that interfered with a neighboring business such as a laundry. Without the tax, the smoke producer would not take into account the effects of the smoke on the laundry; so the tax would be added to the smoke-producer to bring her private incentives into line with the social good-that is, to "internalize" the negative externality of smoke damage via a tax on smoke. One of Coase's insights was that the state could be removed from the picture by giving the smoke producer (or the laundry owner) the right to make smoke (or be smoke-free), and then permitting market exchanges. See R.H. Coase, The Problem of Social Cost in The Firm, the Market, and the Law 95, 101, 105, 114 (1988). Furthermore, Coase concluded that it is irrelevant from the point of view of total output who has the right, so long as transaction costs are low. See id. at 114 ("Such a rearrangement will always take place if it will result in an increase in the value of production."). Of course, one of Coase's main points was that economists such as Pigou had ignored the costs of administering the government solution to the externality problem. See id. at 154,156 . He showed this brilliantly by demonstrating that under the same assumption of costless administration (i.e., zero transaction costs), there is no need for government intervention. 
setting rules for their exchange. ${ }^{7}$ The purpose of this brief article is to do just that in the context of IPRs. ${ }^{8}$

Consider first a hypothetical to which the Coase Theorem applies. Imagine a patent infringer who can produce a patented product more cheaply than the inventor who owns the patent. Whether a transaction is required to produce the efficient outcome depends on whether the patentee has a legal right, but the efficient outcome will be the same. If the inventor holds the right, the higher-valuing infringer can be expected to negotiate a license. If the infringer has the right, she can market her product without negotiating a license. The infringer's superior product will reach the market in either case, although the parties' wealth differs depending on who has the right. ${ }^{9}$

So the Coase Theorem applies to at least some inventor/infringer interactions. At first blush, then, we might be tempted to conclude that allocation of initial entitlements between rival inventors-hence, IPRs themselves-is irrelevant to an efficient outcome: the indifference thesis holds. But before we make this leap, we must catalogue some important differences between intellectual property and the sorts of physical externalities with which Coase was concerned. In the first place, unlike his famous smoke or cattle examples, ${ }^{10}$ it is not always easy to detect externalities in the invention context. The problem of detecting externalities in the IPR field implicates an additional difference between IPRs and other Coasian interactions. As Arrow has pointed out in his "paradox of information," without a property right, the licensor is in a pickle: if in trying to strike a deal she discloses her idea (e.g., the technology she invented), she has nothing left to sell, but if she does not disclose anything the buyer has no idea what is for sale." ${ }^{11}$ Patents (and to a lesser extent trade

7. See Thräinn Eggertsson, Economic Behavior and Institutions 105 (1990) ("Coase's main contribution... was to arouse our awareness of the implications of positive transaction costs.").

8. Although I did discuss this issue in my patent law casebook, see Merges, supra note 2, at 776-77, I was not the first to do so. See Stanley M. Besen et al., Copyright Liability for Cable Television: Compulsory Licensing and the Coase Theorem, 21 J.L. \& Econ. 67 (1978). See also John W. Schlicher, Patent Law: Legal and Economic Principles $\$ \S 2.04-2.05$ (1992) (applying Coase Theorem to laws protecting information production and bargaining problems in agreements to produce information).

9. Obviously, I am using "infringer" loosely in this sentence to preserve the symmetry of the examples. One who has the right to use something cannot be an infringer. Perhaps "second comer" or "follow-on creator" would be better. A straightforward numerical example can be found in Merges, supra note 2, at 766-77.

10. For details of the smoke example, see supra note 6 .

11. See Kenneth J. Arrow, Economic Welfare and the Allocation of Resources for Invention, in The Rate and Direction of Inventive Activity 609, 615 (National Bureau of Economic Research ed., 1962). Many examples of this well-known phenomenon can be found; for one drawn from history, see Tom D. Crouch, The Bishops Boys: A Life of Wilbur and Orville Wright 346-48 (1989) (describing Wright brothers' dilemma when, prior to filing for a patent on their airplane design, they were approached by the government to reveal their invention; they proposed a large up-front payment or "bond" to solve the problem). 
secrets) protect the licensor's property so she can confidently discuss it in the context of striking a Coasian bargain. A farmer adjacent to a cattle ranch will normally have no trouble determining when cattle have trampled her crops, for purposes of assessing the need for (and price of) a compensatory exchange. In the IPR context, there is no smoky soot or wandering cattle to serve as an unambiguous marker, although a direct copy of an apparent feature may appear on the market in some cases. Creators very often work far away from each other, and at different times. Prior creative works or inventions may be incorporated into products unintentionally.

Detection aside, in many cases there will be disagreements about whether and to what degree the prior work added to the value of the subsequent one. Prior creations may be minor inputs that are subsequently incorporated into a larger product, or they may take on a form similar to a common "ancestor" work. In the case of patented inventions, an infringer may have no way of knowing that her own independent invention is an infringement, or that, at the time she makes her investment decisions, a patent even exists. ${ }^{12}$ In such a setting, there will be many more arguments over the existence of externalities than in the examples used by Coase. ${ }^{13}$ To the extent that IPRs deal with abstract rights over creative works, there will often be profound debate about whether there are any externalities at all that must be "internalized" via a property right.

Even assuming they agree on the existence of an externality, the two creators are unlikely to agree on its severity. A second creator who has drawn on an earlier work, for example, is much more likely to believe (or at least argue) that the unique elements in her work or product are responsible for whatever success it has had. Anyone who has negotiated an IPR license (or the sale of any unique asset) can only yearn for the sort of mutually agreed-upon schedule of harms and benefits Coase draws up in

12. The same is true in trademark law. Like one who independently invents an already patented device, one who begins using a similar trademark is an infringer regardless of the fact that the trademark owner's business was completely unknown to the infringer. This situation might be described as a form of asymmetric information, but the point in the text is meant to go further. Even where the two parties, the creators of the prior and subsequent works, agree that the latter had access to information about the former's work, there may be disagreements over whether and to what extent knowledge of this work assisted in the creation of the subsequent work, or adds value to it.

13. Cf. Douglass C. North, Structure and Change in Economic History 16 (1981). As North points out:

Throughout history there has almost always been an immense gap between the private and the social returns to invention and innovation. The problem is one of specifying property rights over ideas and their application to economic activity; it has been more difficult to devise property rights over technological development than over products or resource inputs. The difficulty of measuring the dimensions of intellectual property and innovations and of enforcing any such property rights has been a basic reason for the divergence between private and social benefits.

Id. 
his hypotheticals. The problems with producing such a schedule in the IPR field result from the abstract quality of the benefits conferred by prior works and the cumulative, interdependent nature of works covered by IPRs. Valuation, then, is at least as great a problem as detection.

One corollary of the valuation problem is the heightened possibility of strategic behavior. Coasian bargaining assumes that the parties will equitably divide-rather than fight over-the cooperative surplus to be gained via the bargain. This equitable division is unrealistic in many cases, as noted by Robert Cooter and others. ${ }^{14}$ Indeed, I have argued elsewhere that overlapping IPRs on distinct aspects of a single product can create very knotty valuation problems. ${ }^{15}$ The famous case of blocking patents, a most interesting institution from the property rights perspective and a textbook case of bilateral monopoly in action, often creates problems of this sort. (When $A$ owns a patent on a broad class of products and B owns a patent on a specific product in that class, A and B are

14. See Robert D. Cooter, The Cost of Coase, 11 J. Legal Stud. 1, 23 (1982).

15. See Robert P. Merges, Intellectual Property Rights and Bargaining Breakdown: The Case of Improvement Inventions and Blocking Patents, 61 Tenn. L. Rev. (forthcoming 1994). I recommend occasionally excusing the subservient patent holder ( $B$ in the example in the text) from infringement liability when the holdup problem is severe. The holdup may be severe, for example, when the invention covered by an improvement patent, which cannot be implemented without permission of the holder of an original, dominant patent, contributes a very large proportion of the total value of the original-plusimprovement combination. Historically, bargaining breakdowns have often occurred in this situation, the social costs of which justify a sort of "patent fair use" or "efficient infringement" principle. Fortunately, while such situations are serious given that they often involve significant new technologies, they are relatively rare. In the great run of cases, the ingenious institution of blocking patents balances the rights of original creators and subsequent improvers rather nicely. Interestingly, no such institution exists in the law of copyrights under which a follow-on creator would be prohibited from appropriating and adding to the copyrighted material of an original creator. It has been argued that to deny the derivative artist a copyright in his additional creative efforts, to the extent they are pervaded by the original work, diminishes his incentives to create new works based upon copyrighted material:

The rule [denying copyrightability for unauthorized derivative works] is, however, hard to justify when applied to derivative works such as the motion picture in Sheldon v. MGM in which the underlying work represents only a small part of the value of the derivative work but, because it underlies the whole, will defeat copyright protection for the entire derivative work. Just as an injunction against the motion picture gave plaintiff there a greater return than was needed to induce his investment in the underlying work, so depriving the motion picture owner of all protection against others will give it far less return than is needed to justify investment in the derivative work.

Paul Goldstein, Derivative Rights and Derivative Works in Copyright, $30 \mathrm{~J}$. Copyright Soc'y 209 (1983) (citing Sheldon v. MGM, 309 U.S. 390 (1940)). See also Wendy J. Gordon, Toward a Jurisprudence of Benefits: The Norms of Copyright and the Problem of Private Censorship, 57 U. Chi. L. Rev. 1009 (1990). Perhaps the best explanation for the lack of a doctrine of "blocking copyrights" is copyright law's policy favoring the reputational interest of authors: by requiring ex ante licensing of anyone who wishes to incorporate a copyrighted work into another work, the law ensures that the owner of the copyrighted work will completely control all manifestations of it. 
said to hold blocking patents with respect to the specific product of B's patent: neither can commercialize the product covered by B's patent without first obtaining a license from the other.) I recommend that the law sometimes excuse holders of subservient blocking patents ( $B$ in the example above) from liability, as a way of influencing right-holders to reach agreement. Whatever the policy solution, however, the problem of blocking patents teaches a valuable lesson: the Coasian picture of two economic agents agreeing on the joint costs and benefits of each level of production is out of place in at least some, and perhaps most, cases involving IPRs. ${ }^{16}$ Ultimately, valuation is significantly trickier than that described by Coase and others in hypotheticals of the farmer/rancher variety.

So far, I have described problems of detection and valuation. Another potential problem with the Coasian construct as it applies to intellectual property is its avowed lack of concern for the distribution of resources. Coase sets out to show that total output in an economy is unaffected by the initial allocation of rights. The farmer and the cattle rancher, for example, will bargain to produce the same mix of products regardless of who holds the right. ${ }^{17}$ At the same time, the one holding the right will have more money after the bargain is struck. ${ }^{18}$

16. If more proof is needed, consult a decision setting damages for patent infringement-a form of ex post valuation that is obviously difficult and inexact. See Merges, supra note 2, at ch. 9.

Valuation problems also extend beyond patent law; they are pervasive in copyright as well. Consider the complex cases that try to apportion the relative contributions of infringing and non-infringing portions of an aggregate copyrighted work. In the typical case, the holder of a copyright on a work seeks to enjoin commercialization of a larger work that incorporates it. The classic example is Sheldon v. Metro-Goldwyn Pictures Corp., 309 U.S. 390 (1940), discussed supra note 15. Plaintiff's play was copied by MGM in a motion picture that also included substantial original contributions by MGM-such as a famous cast and significant advertising expenditures. The Supreme Court affirmed the lower court's order that plaintiff be awarded only one-fifth of defendant's profits. See id. at 409. The Court's heroic attempt to block plaintiff's holdup attempt was laudable. Nevertheless, the one-fifth royalty appears completely arbitrary. See id. at 407-09 (estimates by expert witnesses from film industry of percentage of value contributed by play ranged from $0 \%$ to $12 \%$; court settled on $20 \%$ to insure no harm to copyright holder). This arbitrariness, together with the felt necessity of litigation up to the Supreme Court, provides indirect evidence of the severity of valuation problems.

17. See Cooter, supra note 6 , at 66 ("As with ordinary goods, the gains from trading legal entitlements are not exhausted until each entitlement is held by the party who values it the most."); Merges, supra note 2, at 766-67 (applying this "strong form" of the Coase theorem to intellectual property, specifically patents).

18. Coase claims in a later commentary that, in fact, any differences in the distribution of resources will be eliminated as the cost of related resources rises (or falls) to reflect the new income distribution. See Coase, supra note 6 , at $157,170-74$. The limitations of this point are best captured in a direct quote, taken from a passage discussing the rancher/farmer example described earlier in the text:

[I]f the rule of liability is known, the amount that will have been paid to acquire the land will reflect this, less being paid for the ranching land and more for the farming land when compensation has to be paid [to the farmers] than when it 
Although the overall goal of intellectual property law is often described in allocational efficiency terms (i.e., to increase economic output by overcoming market failures associated with the public goods quality of creative works), there is often an undercurrent of concern with the distribution of resources. Therefore, the law would seem to favor allocation of rights to creators rather than infringers, even if the parties will bargain to the efficient outcome regardless of the allocation. As a result of this builtin distributional bias in intellectual property, in some cases an inventor reaps royalties even though total output is the same as it would be if the infringer were not liable.

The problem of transaction costs is the most blatant one in applying the Coase theorem to IPRs. Despite a few brave attempts to assume away the obvious, ${ }^{19}$ those who have considered the application of the Coase theorem to IPRs have noted the pervasive presence of transaction costs. ${ }^{20}$ Thus, analysis conventionally begins with a discussion of where rights should reside in the first instance, given high (and intractable) transaction costs. In addition, these arguments are sometimes taken a measure further: they are used to justify the imposition of compulsory licenses, that is, liability rules. Thus, a common rationale for the several statutory compulsory licenses in copyright law is that they are needed in order for certain types of exchange to take place. Transaction costs preclude the formation of a market for certain types of rights; ${ }^{21}$ in the absence of statu-

does not have to be paid. The wealth of the land-owners would thus remain the same, changes in the amount paid for the land offsetting the changes in the flow of payments brought about by a difference in the legal [rule] ....

Id. at 172. Even if such an adjustment were possible in some markets, it is very hard to imagine the prices of inputs to creators or infringers (e.g., labor, art supplies, and lab equipment) changing in response to a change in the legal rule on protection of creative works, given the diversity and diffuseness of these inputs and the fact that so many have alternate uses outside the creation of protectable works. Thus, the locus of rights in the creator/infringer context will almost surely have distributional consequences.

19. See Jack Hirshleifer, The Private and Social Value of Information and the Reward to Inventive Activity, $61 \mathrm{Am}$. Econ. Rev. 561, 571-72 (1971) (arguing that, since inventors have "inside information" about their inventions, they can reap gains by investing in assets that their inventions will make more valuable and selling short assets that their inventions will make less valuable; because of this inside information, inventors might be overcompensated for their inventions); Ben T. Yu, Potential Competition and Contracting in Innovation, 24 J.L. \& Econ. 215 (1981) (presenting model in which activities of prospective innovators are coordinated by central authority to reduce rent dissipation from competitive inventing).

20. See, e.g., Schlicher, supra note $8, \S \S 2.04-2.05$ (1992).

21. See, e.g., Ralph Oman, The Compulsory License Redux: Will It Survive in a Changing Marketplace?, 5 Cardozo Arts \& Ent. L. Rev. 37 (1986) (describing the interplay between transaction costs and the need for compulsory licensing); Lorna Veraldi, Note, Cable Television's Compulsory License: An Idea Whose Time Has Passed?, 25 N.Y.L. Sch. L. Rev. 925, 949-50 (1980) (concluding, on the basis of transaction costs, that there is no evidence that the cable compulsory license, if abolished, would be replaced with market transactions). 
torily mandated transactions, none would take place. Some of Reichman's comments reflect a similar judgment. ${ }^{22}$

I have argued elsewhere that this reasoning is flawed in some cases. ${ }^{23}$ Indeed, I suggest that the presence of high transaction costs does not halt exchanges but encourages both producers and users to invest in institutions that lower the cost of certain types of exchanges. Even though there are many dispersed buyers (and sellers) of IPRs, and even though the transaction costs of IPR exchanges are otherwise high, ${ }^{24}$ the strong property rule baseline often works quite well. The frequency of contracting in many markets for IPRs-an underdeveloped theme in most of the entitlements literature ${ }^{25}$-gives rise to a myriad of institutions (broadly defined) designed to streamline the exchange of property rights. Institutions such as $\mathrm{ASCAP}^{26}$ and patent pools ${ }^{27}$ arise when firms modify the strong property rule baseline of intellectual property law by contracting into liability rules. More importantly for property rights theory in general, the property rule facilitates this adjustment. By contrast, statutory liability rules work against the flexible, voluntary institutions that are formed to overcome the costs faced by transactors.

While there is some evidence that these institutions are beginning to form in the software field (particularly multimedia products such as CD-

22. See Reichman, supra note 2 , at 2447.

23. See Robert P. Merges, Contracting into Liability Rules: Institutions Supporting Transactions in Intellectual Property Rights 22-24 (1994) (unpublished manuscript on file with the Columbia Law Review). I am not alone: in comments on an earlier draft of this paper, Paul Goldstein noted that transaction costs provide a dubious rationale for many of the compulsory license provisions of the copyright statute. See also Wendy J. Gordon, Fair Use as Market Failure: A Structural and Economic Analysis of the Betamax Case and Its Predecessors, 82 Colum. L. Rev. 1600, 1613 (1982) (arguing that other factors can explain some compulsory licenses, e.g., antitrust concerns). rule:

24. Calabresi and Melamed assert that these conditions are likely to lead to a liability

Often the cost of establishing the value of an initial entitlement by negotiation is so great that even though a transfer of the entitlement would benefit all concerned, such a transfer will not occur. If a collective determination of the value were available instead, the beneficial transfer would quickly come about.

Calabresi \& Melamed, supra note 3, at 1106.

25. For example, to illustrate the desirability of liability rules, Calabresi and Melamed describe a one-shot "eminent domain" example where adjoining landowners sell their individual parcels to a single buyer. No repeat-play examples are given, which is not surprising given the authors' emphasis on delineating a typology of initial entitlements. See id. at 1106-07.

26. ASCAP, the American Society of Composers, Authors, and Publishers, is the private copyright organization that collects composers' performance rights for licensing to radio stations and nightclubs.

27. Patent pools are industry-wide agreements, often accompanied by administrative structures, to centralize all firms' patents for automatic out-licensing or to cross-license each others' patents. 
ROM) ${ }^{28}$ and biotechnology, ${ }^{29}$ the best evidence that they will do so is the history of other industries. Since its infancy, radio broadcasting has involved an enormous transactional load to operate effectively. Likewise, many technology-intensive industries in the early twentieth century developed only through the use of a myriad of technologies whose patents were owned by separate firms. Yet, in each case, institutions, such as AS$\mathrm{CAP}$ and patent pools, emerged over time to facilitate many different combinations of separate IPRs. Until we know for sure that software and biotechnology are exceptions, we should, for the most part, give these industries a chance to evolve similar institutional arrangements. ${ }^{30}$

I cannot argue these points in detail here. I mention them because the study of IPR institutions calls into question the static nature of the usual Coase Theorem construct. The initial assignment of rights receives all the attention under this analysis. Subsequent market and institutional

28. As one commentator recently noted:

[A group of] photographers [is] trying to flesh out a new set of copyright arrangements for photographs .... [T] his sort of licensing has been going on in the music recording industry for years, managed by a company [sic] known as ASCAP ....

-...

"Most [CD-ROM publishers] I talk to are very interested in having the industry get together to make some practical [licensing] standards," [Jane] Kinne [, of Comstock, a New York stock photography agency] says ... " "They're not interested in investing a lot of money in a product that is going to be shot down a couple of years later in a lawsuit."

Paul Karon, Electronic Publishing Faces Legal Traps over Copyrights, InfoWorld, Mar. 9, 1992, at S-70.

29. So-called "materials transfer agreements," or "MTAs," contracts under which biotechnology laboratories exchange cell lines and other research tools and findings, are now very common. See Charles E. Lipsey et al., Protecting Trade Secrets in Biotechnology, in Protecting Trade Secrets 1986, at Exhibit K (PLI Patent, Copyright, Trademarks, \& Literary Property Course Handbook Series No. 224, 1986). A uniform, standardized MTA has been proposed by the Association of University Technology Managers (AUTM), suggesting that standard contractual terms-a form of transaction-cost reducing industry coordination-are beginning to emerge. See Interview with Sandy Shotwell, AUTM member and participant in project to draft the Uniform Biotechnology Material Transfer Agreement (UBMTA), in Washington, D.C. (Feb. 1994).

30. Waiting for these industries to develop institutional arrangements does not mean that we should allow property rights to proliferate unchecked in these industries. Software patents, for example, may well be a bad idea, as would be the granting of patents on "raw" gene sequences such as those the National Institute of Health applied for in 1992 (and subsequently dropped). See Rebecca S. Eisenberg, Technology Transfer and the Genome Project: Problems with Patenting Research Tools, 5 Risk: Health, Safety, \& Environment 163-75 (1994); Robert P. Merges, Patenting Human DNA and Legal Issues Related to the Experimental Use Exception (Nov. 1, 1993) (unpublished report submitted to the Office of Technology Assessment of the U.S. Congress, on file with the Columbia Law Review). I mean only to suggest that, when the legal system makes a reasoned decision to grant certain IPRs, courts should enforce these rights through injunctions (i.e., a property rule) and thereby encourage private transactions. 
adjustments are either ignored or subsumed in a sweeping price adjustment scenario. ${ }^{31}$

\section{InCorporating Transaction Costs: Property vs. Liability Rules}

Coase's point was that transaction costs determine where rights should reside. The property/liability rule dichotomy put forth by Guido Calabresi and A. Douglas Melamed systemized thinking about rights allocations in the presence of transaction costs. ${ }^{32}$ They argued that the extent and nature of transaction costs in a particular case dictate whether one of the parties to the Coasian bargain ought to have an absolute property right or simply the right to collect damages caused by the other party's encroachment (i.e., a "liability rule"). This doctrine holds that the following factors point toward adoption of a property rule: few parties, difficult valuation problems, and otherwise low transaction costs. Other factors indicate that a liability rule might better effectuate the bargain: many parties (especially when one party has the power to "holdup" the entire enterprise), the likelihood of strategic bargaining, and otherwise high transaction costs. ${ }^{33}$

Thus, in the Calabresi and Melamed framework, a property rule allows the right-holder to set her own asking price through ex ante negotiations when someone begins to interfere with the holder's activities. ${ }^{34}$ Under a liability rule, however, a court sets the price in a proceeding that typically takes place after the right has been infringed. The choice of which rule to apply depends on the degree and nature of the transaction costs. 35

IPR cases fit the criteria set up by Calabresi and Melamed for application of a property rule: (1) there are only two parties to the transaction; (2) the costs of a transaction between the parties are otherwise low; and, most importantly, (3) a court called on to set the terms of the exchange would have a difficult time doing so quickly and cheaply, given the specialized nature of the assets and the varied and complex business environments in which they are deployed. Because each asset covered by an IPR is in some sense unique-a characteristic guaranteed by various requirements for protectability in intellectual property statutes-it is difficult for a court in an infringement case to properly value the right-holder's loss. Hence, the parties should be left to make their own deal. For example, recall the problems the court faced in Sheldon v. Metro-Goldwyn Pictures Corp..$^{36}$ valuing the contribution made by the copyrighted play to the film that incorporated some of its plot elements. Courts are simply not wellsituated to make difficult valuations of this sort; surely the parties could

31. See Coase, supra note 6 , at 170-74.

32. See Calabresi \& Melamed, supra note 3, at 1106-07.

33. See id. at 1106-08.

34. See id. at 1105 .

35. See id. at 1106-10.

36. 309 U.S. 390 (1940); for further discussion, see supra notes 15 and 16. 
be expected to do at least as well given their intimate knowledge of the play, the film, and relevant industry norms. Property rules insure that this knowledge is brought to bear in cases in which valuation is difficult.

A liability rule should prevail, by contrast, when it is relatively easy to determine the value of an exchange by reference to an objective market price. ${ }^{37}$ Contracts cases provide the paradigmatic example. Often, a court can accurately calculate the appropriate compensation for the injured party. This ability to calculate damages accurately has the added benefit-often touted as the primary rationale for money damages in contract cases - of encouraging breach where the breaching party can both fully compensate the injured party and enter into a substitute transaction with someone else who values the breaching party's performance more highly. This is the concept of the efficient breach: a compensatory remedy predicated on the ease of valuing the costs of breach and the desirability (i.e., Pareto optimality) of directing the breaching party's performance where it is most valued. ${ }^{38}$

A persistent minority, however, advocates a property rule (i.e., specific performance remedy) as a baseline remedy even in contracts cases. (It is interesting that many of the arguments made from this position mirror conventional wisdom in the IPR field. ${ }^{39}$ ) In this context and others, recent scholars have become ever more enamored of the logic of property rules. ${ }^{40}$ Even the foundational work of A. Mitchell Polinsky,

37. See Cabresi \& Melamed, supra note 3, at 1106-08.

38. Less commonly, a court will order specific performance. This equitable remedy requires the breaching party to fully perform the contract, rather than merely to compensate the injured party for the costs of the breach. A number of celebrated law review authors have argued that the frequency of the two remedies should be reversed, with specific performance being designated as the default remedy. According to scholar Thomas Ulen,

[t]his method of protecting entitlements-a method that the authors [Calabresi and Melamed] call one of property rules-is the most efficient means when the level of transaction costs between the parties in conflict is low. Only in those circumstances is it possible for voluntary exchange to determine which of the competing uses is of higher value.

Thomas S. Ulen, The Efficiency of Specific Performance: Toward a Unified Theory of Contract Remedies, 83 Mich. L. Rev. 341, 367 (1984). See also Anthony T. Kronman, Specific Performance, 45 U. Chi. L. Rev. 351 (1978); Alan Schwartz, The Case for Specific Performance, 89 Yale L.J. 271 (1979). But so far, courts have, for the most part, adhered to the traditional default of money damages for breach. See Edward Yorio, In Defense of Money Damages for Breach of Contract, 82 Colum. L. Rev. 1365 (1982). The interesting point is that many of the arguments made by the proponents of specific performance as the proper norm in contract law have long been made-and accepted-in intellectual property law.

39. See Schwartz, supra note 38 ; Ulen, supra note 38.

40. The interesting contribution of Haddock, McChesney, and Spiegel, for example, sets out a general theory supporting the dominance of property rules based on an Edgeworth Box model. See David D. Haddock et al., An Ordinary Economic Rationale for Extraordinary Legal Sanctions, 78 Cal. L. Rev. 1 (1990). On the Edgeworth Box, a simple model of the bargaining range between a seller and buyer, and the related notion of the "contract curve," see Donald N. McCloskey, The Applied Theory of Price 88-90 (1982). In 
who argued forcefully that in many situations there is little difference between property rules and liability rules, ${ }^{41}$ supports the strong property rule baseline for IPRs. Polinsky argued that a property rule is superior to a liability rule when "the court lacks information about both damages and benefits." ${ }^{2}$ Without accurate information, the damages may be set below

the Haddock et al. model, a liability rule returns the plaintiff to the indifference curve she was on at the outset of the transaction. This rule deprives that party of the opportunity to capture some of the surplus of a mutually advantageous bargain. (This bargain is usually predicted to lie on the intersection of two indifference curves reflecting higher utility for each party.) In this, Haddock et al. resembles several earlier papers. Polinsky, in a discussion of strategic bargaining under both property and liability rules, frequently mentions the availability of "gains from trade." See, e.g., A. Mitchell Polinsky, Resolving Nuisance Disputes: The Simple Economics of Injunctive and Damage Remedies, 32 Stan. L. Rev. 1075, 1092 (1980). Another paper points out that when two neighboring activities involve benefits as well as costs to the two parties, and a liability rule merely places one party in the position she would be in absent any interaction with the other party, each party might prefer to bear liability. This would then allow that party to reap all the proximity gains while paying out a measure of damages that, by assumption, yields net profits. See Susan Rose-Ackerman, I'd Rather Be Liable Than You: A Note on Property Rules and Liability Rules, 6 Int'l Rev. L. \& Econ. 255, 255 (1986). David Schap argues that when court-set damages systematically fail to reflect the plaintiff's full economic costs, for example, when the plaintiff suffers "psychic costs" that are difficult for a court to value, property rules should be preferred. See David Schap, The Nonequivalence of Property Rules and Liability Rules, 6 Int'l Rev. L. \& Econ. 125, 129 (1986). Note the applicability of Schap's thesis to IPRs which, I have argued, are rife with valuation problems. The failure of liability rules to allocate fairly the bargaining surplus justifies the award of "extraordinary" (i.e., supracompensatory) damages in certain cases, and points toward a property rule in others. While this is a different rationale for a property rule than the one presented here, it places similar emphasis on the importance of bargaining.

At the same time, the assumption that a liability rule merely returns the plaintiff to the same utility level she occupied before the transaction does not ring true in at least one situation with which I am familiar: damages in patent cases. The benchmark remedy of the patentee's "reasonable royalty" is calculated on the basis of a "hypothetical negotiation" between patentee and infringer, conducted prior to the commencement of infringement. See Merges, supra note 2, at 786-88. This measure of damages, though clearly a liability rule (since it applies to past infringements), most assuredly does not seek to return the patentee to her initial indifference curve; it clearly envisions giving the patentee a share of the value added by the infringer. It, therefore, attempts to mimic a property rule, thus eliminating the criticism of liability rules levelled by Haddock et al.

41. See Polinsky, supra note 40 , at 1111. For example, Polinsky showed that strategic bargaining, which many commentators had associated exclusively with property rules, is also present in many cases under a liability rule. This follows from the observation that there will often be a difference between the court-set damages and the plaintiff's actual injury, which creates the same opportunities for (and costs of) bargaining as a property rule. Interestingly, one common practice in the music industry appears to confirm this observation. This is the practice of bargaining around the statutory compulsory licensing regime for "mechanical" or "cover" royalties via the Harry Fox Agency, a New York "clearinghouse" for performance rights. See Merges, supra note 23, at 31 (noting that, unlike many of the compulsory licensing provisions described below, the statute permits parties to contract around the statutory rate). See generally Ian Ayres \& Eric Talley, Solomonic Bargaining: Dividing a Legal Entitlement to Facilitate Coasean Trade, 104 Yale L.J. (forthcoming 1994) (describing bargaining in the shadow of a liability rule).

42. Polinsky, supra note 40 , at 1112 . 
the actual level of harm, encouraging the "injurer" (or infringer) to engage in an excessive level of activity-in our case, increased infringement. Thus, the typical IPR transaction meets Polinsky's conditions for the dominance of a property rule, despite his general point that there is often less difference between these forms of entitlement than others had presumed. 43

\section{Exceptions to the Strong Property Rule for IPRs}

All familiar with the IPR field recognize the strong presumption in favor of injunctions. As one court put it, in ruling that an injunction is the normal remedy for patent infringement: "Without the right to obtain an injunction, the right to exclude granted to the patentee would have only a fraction of the value it was intended to have, and would no longer be as great an incentive to engage in the toils of scientific and technological research." 44 Copyright shares the same baseline. As Paul Goldstein says, "[c] ourts exercise their statutory authority to grant temporary injunctive relief more readily in copyright actions than in other intellectual property cases. Final injunctive relief, though similarly discretionary, is ordinarily available." 45 Moreover, as Goldstein points out, copyright shares similar rationales for its strong property rule:

[A]lthough coercive relief [which includes injunctions] will sometimes overcompensate the copyright owner, monetary relief alone will often undercompensate it. Damages are hard to prove, the infringer's profits may be less than the copyright owner could have earned in the same market, and statutory damages . . . may systematically undercompensate the copyright owner for its business risk in producing the work. ${ }^{46}$

Despite widespread acceptance of a property rule, departures from it are not unknown in the IPR context. It is worth reviewing these briefly, and thereby implicitly asking whether Reichman has justified his own proposed departure in his paper.

43. Alan Schwartz pursued a similar tack in a recent article, where he argues in favor of enforcement of contractual provisions stipulating a specific performance remedy. See Alan Schwartz, The Myth That Promisees Prefer Supracompensatory Remedies: An Analysis of Contracting for Damage Measures, 100 Yale L.J. 369, 371 (1990). Schwartz presumes that the presence of such a term in a contract is a sure sign that the parties have had difficulty valuing the potential loss from nonperformance of the contract; regardless of the merits of this as a general proposition, the statutorily-defined status of IPRs as unique assures that it is realistic in the cases of interest to me.

44. Smith Int'l, Inc. v. Hughes Tool Co., 718 F.2d 1573, 1577 (Fed. Cir.), cert. denied, 464 U.S. 996 (1983). See generally Bradford J. Duft, Patent Preliminary Injunctions and the United States Court of Appeals for the Federal Circuit, 65 J. Pat. Off. Soc'y 131 (1983) (arguing that judicial discretion to grant preliminary injunctions is neither prejudice nor whim). The Court of Appeals for the Federal Circuit has softened the "per se" injunction rule of Smith to a limited extent in more recent cases. See Merges, supra note 2, at 749-77.

45. 2 Paul Goldstein, Copyright: Principles, Law and Practice $\$ 11.0$, at $247-48$ (1989) (footnotes omitted).

46. Id. at 249 (footnotes omitted). 
There are two general exceptions to the strong property rule for IPRs. Compulsory licenses coerce IPR holders to transfer certain rights to certain classes of licensees. In addition, various doctrines, best explained as responses to market failure of one kind or another, excuse infringement of otherwise protected works. ${ }^{47}$

Defenders of the exceptions say high transaction costs provide a justification. I shall not touch on the second exception, market failure, though there is much of interest to say about it. Regarding compulsory licenses, I have, as noted earlier, taken exception with those who would rush to implement these licenses before institutions have a chance to emerge to reduce IPR transaction costs.

Compulsory license provisions set automatic terms for IPR transactions. In general, they are available for patents only as a remedy for violation of the antitrust laws. ${ }^{48}$ In copyright law, however, although they are still the exception, they are found more frequently. Currently the copyright statute provides for compulsory licensing of four classes of works: (1) musical recordings; ${ }^{49}$ (2) songs played on jukeboxes; ${ }^{50}$ (3) certain

47. In the eyes of some commentators, a middle ground of ongoing, compensated infringement should be permitted: a liability rule crafted by judges. See Pierre N. Leval, Toward a Fair Use Standard, 103 Harv. L. Rev. 1105, 1131, 1134 (1990) (prescribing no injunction remedy in cases where private unpublished papers of authors or other public figures are infringed in course of writing biography). In a case later reversed by the Second Circuit, Salinger $v$. Random House, Inc., Judge Leval wrote (in dictum): "With all respect for the rights of a copyright owner, a publication should not be enjoined where the degree of infringement is trifling and inconsequential." Salinger v. Random House, Inc., 650 F. Supp. 413, 426 (S.D.N.Y. 1986), rev'd, 811 F.2d 90 (2d Cir. 1987). See also Abend v. MCA, Inc., 863 F.2d 1465, 1478, 1479 (9th Cir. 1988), aff'd sub nom. on other grounds, Stewart v. Abend, 495 U.S. 207 (1990) (copyrighted story, basis of film "Rear Window," directed by Alfred Hitchcock and starring Jimmy Stewart and Grace Kelly, infringed by showing of film after copyright grant lapsed; but copyright holder entitled only to continuing royalty on film profits, rather than injunction). See generally Ralph S. Brown, Civil Remedies for Intellectual Property Invasions: Themes and Variations, Law \& Contemp. Probs., Spring 1992, at 45, 51-52 (identifying two classes of cases where preliminary injunctions are sometimes denied: (1) unpublished papers; and (2) copyrighted works incorporated into larger works where the license for the copyrighted work is terminated under the grant-renewal provision of the Copyright Act).

Overtones of a market failure theme may be heard where infringing parodies qualify for the fair use defense. See Fisher v. Dees, 794 F.2d 432, 437 (9th Cir. 1986) ("Parodists will seldom get permission from those whose works are parodied. Self-esteem is seldom strong enough to permit the granting of permission even in exchange for a reasonable fee .... The parody defense to copyright infringement exists precisely to make possible a use that generally cannot be bought."); Harriette K. Dorsen, Satiric Appropriation and the Law of Libel, Trademark, and Copyright: Remedies Without Wrongs, 65 B.U. L. Rev. 923 (1985) (collecting cases). See generally Gordon, supra note 23; Robert P. Merges, Are You Making Fun of Me? Notes on Market Failure and the Parody Defense in Copyright, $21 \mathrm{Am}$. Intell. Prop. L. Ass'n Q.J. 305 (1993).

48. See Merges, supra note 2, at 906-08.

49. See 17 U.S.C. $\$ 115$ (1988). See infra notes 59-64 and accompanying text.

50. See 17 U.S.C. $\$ 116$ (Supp. V 1993). See also Scott M. Martin, The Berne Convention and the U.S. Compulsory License for Jukeboxes: Why the Song Could Not Remain the Same, 37 J. Copyright Soc'y U.S.A. 262, 315-26 (1989) (describing recent 
cable television transmissions; 51 and (4) certain uses of copyrighted works by public television. ${ }^{52}$ Although compulsory licensing is relatively rare, these provisions cover a substantial portion of the copyrighted works in circulation.

Paul Goldstein's important recent treatise on copyright law ${ }^{53}$ cites the conventional justification of these compulsory licensing provisions on the basis of transaction costs. The Act, he states, contains provisions which "set a legislatively predetermined or administratively prescribed rate for specified uses, thus removing negotiation costs as an element of copyright transactions." ${ }^{54}$ But Goldstein has also noted, perceptively, that compulsory licensing provisions may prevent the creation of technologies and organizational innovations that would efficiently administer the rights-clearance process. ${ }^{55}$ To the extent this is correct, one must be hesitant to endorse compulsory licensing.

Indeed, the history of collective rights organizations such as ASCAP $^{56}$ supports the main theoretical point raised earlier: that a property rule for IPRs can be transformed into a voluntary liability rule, in the

negotiated agreement between the collective rights societies and the jukebox trade group for a voluntary licensing system in light of changes to United States copyright law necessitated by United States adherence to the main international copyright union, the Berne Convention).

51. See 17 U.S.C. $\$ 111$ (d) (1988 \& Supp. V 1993) (cable retransmissions). See the related provision on satellite retransmissions by "Superstations" at 17 U.S.C. § 119 (1988 \& Supp. V 1993). Under section 111, a cable system that rebroadcasts a non-network signal from a television station must pay compulsory royalties. Prior to 1993 , these royalties were set by an administrative group known as the Copyright Royalty Tribunal. Under recent legislation, the functions of the Tribunal will be performed by special arbitration panels convened by the Register of Copyrights. See 17 U.S.C. $\S 801$ (1988 \& Supp. V 1993). Interestingly, the new panels, if successful, might be made to approximate the bargaining groups that arrive at industry-wide liability rules as studied in this paper. If they avoid capture, then the legislatively-mandated royalty-setting apparatus may end up being a codification of the type of process that would have arisen in the absence of legislation.

52. See 17 U.S.C. § 118 (1988 \& Supp.V 1993).

53. See 1 Goldstein, supra note 45 .

54. Id. at 19. Paul Goldstein recently noted that

Congress has always tempered the extension of copyright with recognition of the problem of transaction costs-the problem that some individual uses of copyrighted works will be so dispersed that any eventual license royalties will not repay the expense of enforcement and negotiation.

Paul Golstein, Copyright, Law \& Contemp. Probs., Spring 1992, at 79, 84 [hereinafter Goldstein, Copyright]. Goldstein has emphasized that he believes the transaction cost rationale to be dubious in at least some cases. See supra note 23.

55. See Goldstein, Copyright, supra note 54.

56. ASCAP licenses the music performance rights of composers and licenses them out to radio stations, television networks, nightclubs, bars, and the like, almost always on the basis of a "blanket license" covering ASCAP's complete repertoire. See Buffalo Broadcasting Co. v. ASCAP, 546 F. Supp. 274, 277 (S.D.N.Y. 1982), rev'd, 744 F.2d 917 (2d Cir. 1984), cert. denied, 469 U.S. 1211 (1985). Note that an international study of IPR collectives by a group of economists found striking similarities in their basic organization and administration. See Stanley Besen et al., An Economic Analysis of Copyright Collectives, 78 Va. L. Rev. 385-90 (1992). 
form of an effective institution to carry out IPR transactions. ASCAP acts as a central depository for members' rights to control public performances of their works. It issues "blanket licenses" covering the relevant copyrights of all members of the society to radio and television stations and other entertainment outlets. It then monitors the songs played and divides up the total receipts among all members on the basis of a complex pro rata formula. Broadcast Music Incorporated (BMI) is a rival organization, founded expressly to compete with ASCAP, that operates similarly. ${ }^{57}$ These are only two of the seventy-two music-related collective rights organizations that operate in some 182 countries. ${ }^{58} \mathrm{Each}$, to a varying degree, regularizes transactions among holders of strong "property rule" entitlements. In many cases these organizations also establish compensation schemes that operate according to agreed-upon formulas, such as the broadcast-monitoring based system run by ASCAP. These preagreed compensation formulae are akin in many ways to statutory compulsory licensing formulae, which is why I call the institutions that administer them instances of a voluntary, or contractual, liability rule.

One may accept all that has been said so far, yet still object to the notion that strong property rules are to be preferred in the IPR context. The objection might be based on the observation that at most what has been demonstrated in the preceding paragraphs is that property rules can form the basis of operative IPR-exchange mechanisms. What has not been shown, it might be argued, is that statutory liability rules are worse. While one instance cannot serve as a complete response to this objection, I hope that a brief review of the compulsory license for "cover" versions of recorded compositions will illustrate the deficiencies of compulsory licenses.

The history of the mechanical compulsory license begins with the Supreme Court's 1908 ruling in White-Smith Music Publishing Co. v. Apollo Co. ${ }^{59}$ that player piano rolls were not "copies" of copyrighted music. Congress responded by recognizing recording and mechanical reproduction rights as part of the bundle of rights secured by copyright law..$^{60}$ The 1909 Act, however, reflected congressional concern with the market power conferred on the sole dominant music roll firm by virtue of the new right: under the Act, any manufacturer of recordings or mechanical reproductions could use a musical composition as long as that composition had already been licensed for mechanical reproduction and as long

57. On the formation of BMI, see Lee C. White, Musical Copyrights v. The Anti-Trust Laws, 30 Neb. L. Rev. 50, 54-55 (1950) (describing formation of BMI by radio group, the National Association of Broadcasters, in 1941 in response to steep price hike by ASCAP).

58. See David Sinacore-Guinn, Collective Administration of Copyrights and Neighboring Rights 5 (1993).

59. 209 U.S. $1,16-18$ (1908).

60. See Copyright Act of 1909, ch. 320, 35 Stat. 1075 (1909), now superseded by 17 U.S.C. $\$ 115$ (1982) (providing that any copyright owner who licensed a work for reproduction is subsequently subject to compulsory licensing of that work). 
as the manufacturer paid a royalty to the copyright owner. ${ }^{61}$ At the time of the 1909 Act one piano roll firm, the Aeolian Company, dominated the industry. ${ }^{62}$ Congress enacted the mechanical license in response to Aeolian's perceived market power.

There were soon hundreds of record companies, mooting the original rationale for the license. ${ }^{63}$ Yet the record companies had come to rely on the license as a cheap source of material. One might have expected a titanic battle over the preservation of the license, pitting the entrenched record companies against composers and consumers. Yet no such battle ever took place. Composers, apparently accepting the license as an immovable lesson in interest group influence, simply live with it to this day-despite the cries of knowledgeable observers that it continues to distort the market for compositions. ${ }^{64}$

It seems this industry (and others like it) ${ }^{65}$ is locked into a suboptimal liability rule, due to the difficulty of rooting out a compulsory li-

\section{See id. §1(e).}

62. As described by a knowledgeable source:

In anticipation of the [legislation], Aeolian had entered into exclusive contracts with many of the major music publishers of that time for the right to make mechanical reproductions of the works in the repertoires of the publishers. [As a result,] few other manufacturers of piano rolls could acquire the licenses they required to compete in the piano roll business. To thwart this potential monopoly, Congress provided in the 1909 copyright law [for the compulsory license].

Al Kohn \& Bob Kohn, The Art of Music Licensing 310-11 (1992).

63. See Ralph S. Brown \& Robert C. Denicola, Cases on Copyright 497 (5th ed. 1990). See also David E. Kronemyer and J. Gregory Sidak, The Structure and Performance of the U.S. Record Industry, in Entertainment, Publishing and the Arts Fandbook 263, 266 (John D. Viera \& Robert Thorne eds., 1986) ("A surge in demand for prerecorded music in the late 1950s and middle 1960s spawned numerous labels ....").

64. See Register of Copyrights, 87th Cong., 1st Sess., Copyright Law Revision: Report on the General Revision of the U.S. Copyright Law 35 (House Comm. Print 1961):

Removal of the compulsory license would be likely to result in a royalty rate, fixed by free negotiation, of more than the present statutory ceiling of 2 cents. The record companies would, of course, lose the advantage of the lower rate . . . [W] would conclude that the 2-cent ceiling denies authors and publishers the compensation due them for the use of their works.

65. It is certainly not unique in this respect. The jukebox compulsory license, which had also become outdated, proved very hard to eliminate as well. Like record companies, jukebox proprietors were well organized politically. See Brown \& Denicola, supra note 63, at 501:

Attempts to repeal the [jukebox license] were frequent but unsuccessful. The operators who supply machines and the taverns and other establishments who by custom get half the take constitute a broad political base, in contrast to the concentration of the popular music industry in a few urban centers. They had the further advantage of the status quo.

Scott Martin, supra note 50, at 315-27, however, describes the recent negotiated agreement between the collective rights societies and the jukebox trade group for a voluntary licensing system in light of changes to United States copyright law necessitated by United States adherence to the main international copyright union, the Berne Convention. 
cense. This persistence should not be a surprise; studies in the public choice tradition predict just such a status quo bias. Although it is of course not impossible for music publishers and composers to eliminate the license from the statute, the recording companies seem to have at least enough political muscle to block these efforts. ${ }^{66}$

The difficulty of dislodging compulsory licenses even in the face of radically changed circumstances is one of the primary reasons to favor voluntary institutions of the sort I describe earlier in this Comment.

For present purposes, I want to discuss two implications of my observation that compulsory licenses for IPRs are sometimes embraced rashly. First, I find it curious that scholars who have studied legal issues arising out of innovations and other creative works have failed to realize that transactional difficulties are no less capable of calling forth new responses than technological or creative impasses. Perhaps it is an example of Oliver Williamson's point that organizational innovations are understudied and underappreciated. ${ }^{67}$

Second, I have come to see that the rush to implement liability rules in the face of transaction costs reveals a general weakness in property rights theory. Most writing on property rights theory treats only a small number of enforcement techniques and technologies. Furthermore, the literature assumes that these techniques are either exogenously determined or subject only to minor optimization. ${ }^{68}$ One of a small set of

66. At least one experienced witness to the political economy of the IPRs recognizes this. In a recent speech, Rep. William Hughes, then-Chair of the House Subcommittee on Intellectual Property, observed that

I have explored ways to repeal the compulsory licenses but have not met with great success yet. Hope springs eternal, though. There are various reasons for this present lack of success, depending upon which license we are talking about. There is, though, one common thread: some companies, after having adapted to life under a compulsory license, are more comfortable with the devil they know than with the devil they don't. I understand this. But it is interesting that business people who complain about government interference seem reluctant to live in a free copyright market.

Representative William Hughes, before the Copyright Society of U.S.A., in 46 Pat. Trademark and Copyright J. (BNA) 526.

67. See Oliver E. Williamson, Markets and Hierarchies: Analysis and Antitrust Implications 192-93 (1975).

68. See, e.g., Yoram Barzel, Economic Analysis of Property Rights 73-74 (1989) (citing two limited techniques for reducing policing costs: economies of scale in measuring product attributes, and elimination of duplicate measurements); 1 Harold Demsetz, Ownership, Control, and the Firm: The Organization of Economic Activity 31, 41-43 (1988) (describing as "methods which are likely to arise in the market and which will lower the required police cost," vertical integration and bundling of hard-to-police commodities with others that are not); Gary D. Libecap, Contracting for Property Rights 16-17 (1989) (discussing incentives to more precisely define property rights after external shocks such as changes in factor prices or production costs, enforcement technology, or political parameters); Robert C. Ellickson, Property in Land, 102 Yale L.J. 1315, 1320 n.14 (1993) ("In this Article, a land regime is treated as a dependent variable that is affected by technologies, scale efficiencies, risks, ideologies, and other variables regarded as independent."). Libecap comes closest to my interpretation of institution formation as a 
enforcement techniques is assumed to be a more or less natural response to increasing asset valuation coupled with enforcement difficulties. ${ }^{69} \mathrm{My}$ point is twofold: institutions are enforcement technologies too, and they are often generated intentionally to reduce transaction costs and thus increase the value of assets. To the extent institution-building investment is pervasive, we need to incorporate the possibility of a wide range of actively generated endogenous enforcement "technologies"-especially institutions-into our analysis of property rights.

\section{Conclusion}

In this brief paper, I have trained my attention on the application of property rights theory to intellectual property. I hope I have clarified some foundational issues submerged in proposals such as Reichman's. I also hope I have hinted at the potential gains in property rights theory that will flow from a study of the distinct characteristics of intellectual property.

response to high transaction costs; he emphasizes incentives to change property rights (including enforcement techniques) in the political arena. Yet his focus on the legislature as the primary source of enforcement techniques differs substantially from my emphasis on non-legislative institutions.

69. Thus the canonical instance of barbed wire which, once developed, changed the dynamics of western land use and hence the value and nature of property rights in western land. For example, the fine recent article by Robert Ellickson includes this discussion:

The efficiency thesis predicts that innovations in technologies for marking, defending, and proving boundaries lead to more parcelization because they reduce the transaction costs of private property regimes. According to this view; for example, Glidden's invention of barbed wire in 1874 should have stimulated more subdivision of rangeland in the American West. And this indeed appears to have occurred.

Ellickson, supra note 68, at 1330 (footnotes omitted). 